\title{
A note on the use of breadfruit meal (Artocarpus incisus) as a feed ingredient for broiler chickens
}

\author{
C.C. Atuahene, A. Donkoh ${ }^{*}$ D.M. Anang and J. Boateng \\ Department of Animal Science, \\ Kwame Nkrumah University of Science and Technology \\ Kumasi, Ghana
}

(Received 22 January 2002; accepted 9 May 2002)

\begin{abstract}
Breadfruit meal (BFM) (Artocarpus incisus) was evaluated as a poultry feed ingredient in a pilot study. Diets containing 0,25, 50 and $75 \mathrm{~g} \mathrm{BFM} \mathrm{kg-1}^{-1}$ were fed, ad libitum, to 240 day-old broiler chickens for a period of 8 weeks. Birds had free access to water. Performance criteria studied included feed intake, growth rate, efficiency of feed utilization, mortality, carcass and blood parameters. The concentration of BFM in the diet had significant negative influence on feed consumption $(\mathrm{r}=-0.96)$. Brcadfruit meal at 25 and $50 \mathrm{~g} \mathrm{~kg}^{-1}$ slightly improved the growth and feed utilization of broilers. At $75 \mathrm{~g} \mathrm{~kg}^{-1}$ diet, BFM depressed weight gain although not significantly, but feed utilization was similar as in the control group. The level of BFM had no significant impact on carcass yield, mortality, or blood parameters. The kidney, heart, liver and gizzard weights of broilers were also unaffected by the addition of BFM in diets. Breadfruit meal could be included in broiler chickens' diet at concentrations up to $50 \mathrm{~g} \mathrm{~kg}^{-1}$ without an adverse effect on performance
\end{abstract}

KEY WORDS: breadfruit, Artocarpus incisus, broiler chickens, growth performance, blood parameters

\section{INTRODUCTION}

In most developing countries, maize, which constitutes the major portion of poultry diets, is rather expensive and it is the main reason for the high cost of diets (ranging between 70 to $80 \%$ of the total cost of production). Attempts to cut costs

* Corresponding author: e-mail address: armdonkoh@yahoo.uk 
have revolved around finding cheap and available substitutes, generally of agroindustrial origin and under-exploited tropical plant sources. There are many crops of great feeding potential which are currently under-exploited for one reason or another. One of these, the breadfruit (Artocarpus incisus) belongs to the mulberry family, Moraceae.

The breadfruit tree, fast growing and reaching a height of $26 \mathrm{~m}$, is ultra-tropical but much tenderer than the mango tree. The breadfruit is native to a vast area extending from New Guinea through the Indo-Malayan Archipelago to Western Micronesia (Morton, 1987), but has been introduced into other tropical and subtropical parts of the world. The tree bears a number of fruits. In the green stage, the fruit is hard, its interior is white, starchy and fibrous. When fully ripe, the fruit is soft, its interior is cream-coloured or yellow and pasty. The fruit is reportedly of great feeding potential. The dried fruit has been made into flour and improved methods have been explored in Barbados and Brazil with a view to substituting the breadfruit in part for wheat flour in bread making. The combination has been found more nutritious than wheat flour alone. Breadfruit flour is reportedly much richer than wheat flour in lysine and other essential amino acids (Morton, 1987). However, there is a dearth of information on its use as a possible animal feed.

The purpose of this study was to determine the nutrient composition of breadfruit available in Ghana and to further assess the concentration at which breadfruit meal (BFM) could be included in broiler diets without deleterious effects.

\section{MATERIAL AND METHODS}

Samples of matured unripe fruits were harvested, peeled with a knife, cut into small pieces, transferred to a solar dryer for drying at $35-50^{\circ} \mathrm{C}$ to a moisture content of about $110 \mathrm{~g} \mathrm{~kg}^{-1} \mathrm{DM}$, finally ground in a hammer mill to produce the meal and stored in polythene sacks until used in formulations.

The crude protein contents of triplicate $(100 \mathrm{mg})$ BFM samples were determined using the Kjeldahl method (AOAC, 1990). The ash content of the BFM was obtained after heating triplicate $10 \mathrm{~g}$ samples in a furnace at $550^{\circ} \mathrm{C}$ for $24 \mathrm{~h}$. Ether extract (fat) and crude fibre were determined according to the standard procedures of AOAC (1990). Amino acid determinations in BFM were performed following acid hydrolysis using a Beckman $119 \mathrm{BL}$ amino acid analyzer. Triplicate samples $(5-7 \mathrm{mg})$ were hydrolysed in $500 \mu \mathrm{l}$ of $6 \mathrm{M} \mathrm{HCl}$ with $10 \mathrm{~g} \mathrm{l}^{-1}$ added phenol at $110 \pm 1^{\circ} \mathrm{C}$ for $24 \mathrm{~h}$ in vacuum-sealed glass tubes. For the determination of methionine and cystine the hydrolysis was preceded by performic acid oxidation at $0^{\circ} \mathrm{C}$ for $10 \mathrm{~h}$ followed by neutralization with $\mathrm{HBr}$ (Moore, 1963). Tryptophan, being destroyed during acid hydrolysis, was determined chemically by the procedure described by.Miller (1967). Free amino acid molecular weights were used in calculat- 
ing the amino acid yields. The metabolizable energy (ME) of BFM sample was determined by the chromic oxide indicator method (Hill et al., 1960) using glucose as the reference standard and correcting for nitrogen retention.

The composition of the experimental diets appears in Table 1. A control diet, containing no breadfruit meal (BFM) and others in which BFM was incorporated at 25,50 and $75 \mathrm{~g} \mathrm{~kg}^{-1}$ in substitution of maize were formulated.

Two hundred and forty mixed-sex commercial broiler day-old (Afabro) chickens (Afariwaa Farms Ltd, Tema, Ghana) were individually weighed and allotted randomly to the 4 dietary treatments. The trial was conducted according to the completely randomized design and each treatment had three replicates. Starting weights of broiler chickens averaged $45.0 \mathrm{~g}$. The birds were placed and reared in deep litter pens with floor space approximately $0.48 \mathrm{~m}^{2}$ per bird. Broilers consumed feed in mash form and water ad libitum. The trial lasted 8 weeks. Chickens were vaccinated against Gumboro and Newcastle diseases. They were pro-

TABLE 1

Composition of diets fed to day-old broiler chickens

\begin{tabular}{lrrrr}
\hline \multirow{2}{*}{ Item } & \multicolumn{4}{c}{ Level of breadfruit meal, $\mathrm{g} \mathrm{kg}^{-1}$} \\
\cline { 2 - 5 } & 0 (Control) & 25 & 50 & 75 \\
\hline Ingredients, $\mathrm{g} \mathrm{kg}^{\prime}$ & & & & \\
$\quad$ maize & 570.0 & 545.0 & 520.0 & 495.0 \\
breadfruit meal & 0.0 & 25.0 & 50.0 & 75.0 \\
fish meal (63\% CP) & 190.0 & 190.0 & 190.0 & 190.0 \\
soyabean meal & 80.0 & 80.0 & 80.0 & 80.0 \\
wheat bran & 130.0 & 130.0 & 130.0 & 130.0 \\
oyster shell (ground) & 20.0 & 20.0 & 20.0 & 20.0 \\
vitamin and mineral premix ${ }^{a}$ & 5.0 & 5.0 & 5.0 & 5.0 \\
salt (NaCl) & 5.0 & 5.0 & 5.0 & 5.0 \\
Chemical analysis, $\mathrm{g} \mathrm{kg}^{\prime} \mathrm{DM}$ & & & & \\
crude protein & 204.1 & 202.5 & 201.8 & 201.2 \\
crude fibre & 28.7 & 31.2 & 33.4 & 35.8 \\
ether extract & 35.7 & 35.0 & 34.4 & 33.8 \\
lysine & 13.69 & 13.77 & 13.86 & 13.94 \\
methionine & 5.38 & 5.39 & 5.40 & 5.41 \\
cystine & 3.04 & 3.06 & 3.08 & 3.09 \\
ME, MJ kg & 11.89 & 11.80 & 11.70 & 11.61 \\
\hline
\end{tabular}

vitamin-mineral premix supplied ( $\mathrm{kg}^{-1}$ diet): vit. A, $7500 \mathrm{IU}$; vit. $\mathrm{D}_{3}, 2200 \mathrm{IU}$; vit. E. $10 \mathrm{IU}$; vit. $\mathrm{K}$, $1.73 \mathrm{mg}$; riboflavin, $2.5 \mathrm{~g}$; cobalamin, $0.05 \mathrm{mg}$; pantothenic acid, $6 \mathrm{mg}$; niacin, $20 \mathrm{mg}$; choline, $240 \mathrm{mg}$; folic acid, $0.5 \mathrm{mg} ; \mathrm{Mg}, 2.8 \mathrm{mg} ; \mathrm{Fe}, 45 \mathrm{mg} ; \mathrm{Cu}, 5.5 \mathrm{mg} ; \mathrm{Mn}, 55 \mathrm{mg} ; \mathrm{Zn}, 50 \mathrm{mg} ; \mathrm{I}, 0.8 \mathrm{mg} ; \mathrm{Co}$, $0.2 \mathrm{mg}$

${ }^{b}$ calculated from data of $\mathrm{NRC}(1994)$ and the estimated metabolizable energy value of BFM 
tectively medicated against coccidiosis at 3 days of age and again during the third week.

The variables measured for individual replicates of each dietary treatment included: feed intake, body weight gain and feed conversion efficiency (feed:gain). Deaths were recorded daily and the birds were weighed in order to adjust feed conversion. All sick and dead chickens were sent to the Veterinary Laboratory for post-mortem examination. At 56 days of age, 4 broilers from each of the 12 replicates were selected at random, starved of feed for $18 \mathrm{~h}$, killed by cervical dislocation, exsanguinated, defeathered and eviscerated. Carcass yield was calculated from eviscerated weight and liveweight.

To avoid a macrocytic hypochromic anaemia (Christie, 1978) caused by repeated bleeding, the birds were bled only at 5 and 7 weeks of age between 09.00 and $11.00 \mathrm{~h}$. The birds were fasted for $12 \mathrm{~h}$ prior to the collection of blood specimens to avoid postprandial lipaemia (Kirk et al., 1990). Various blood parameters studied included: red blood cell count (RBC), haemoglobin, haematocrit (packed cell volume, PCV) and blood cholesterol. The series of blood tests were performed on blood drawn from the brachial vein. Blood samples for the haematological tests were mixed with the dipotassium salt of EDTA ( $1.5 \mathrm{mg} \mathrm{ml}^{-1}$ blood) as anticoagulant. Erythrocyte (RBC) counting method was similar to that described by Maxwell (1981). Two separate counts were made for each blood sample and the mean of the two counts calculated. The quantity of haemoglobin and the haematocrit (PCV) values were respectively determined by the cyanmethaemoglobin and microhaematocrit methods (Dacie and Lewis, 1975) using the average of duplicate samples. Blood samples for serum cholesterol were allowed to clot to obtain serum and analysed in duplicate for total cholesterol by the procedure outlined by Varley (1962).

The possible effects of BFM on the weight of some body organs were also assessed at 56 days of age. Four birds from each of the 12 replicates with body weight around the mean were selected and killed by cervical dislocation. The kidney, heart, liver and gizzard were excised, weighed immediately and expressed as $\mathrm{g} \mathrm{kg}^{-1}$ body weight.

\section{Statistical analysis}

The dietary treatment effects for all the traits measured were analyzed. The data were subjected to regression analysis to show the effect of including BFM on broiler performance. Differences between means were determined by the use of the Duncan's multiple range test (Steel et al., 1997) and considered significant if $\mathrm{P}<0.05$. The computations were performed using the general linear models procedure of SAS (1987). 


\section{RESULTS AND DISCUSSION}

The proximate and amino acid composition of BFM is presented in Table 2 along with data on maize for comparison. BFM contained more fibre and ash and less crude protein, ether extract and metabolizable energy compared to that of maize. The amino acid profiles show that of the five critical amino acids, BFM had higher levels of arginine $(+23 \%)$, cystine $(+37 \%)$, tryptophan $(+183 \%)$, lysine $(+100 \%)$ and methionine $(+16 \%)$ than in maize. In addition, the ratio of leucine to isoleucine was lower in BFM than in maize (2.12:1 vs $3.47: 1$, respectively).

The effect of BFM on broiler chickens performance are summarized in Table 3. Feed intake by broiler chickens was significantly $(\mathrm{P}<0.01)$ decreased as the level

TABLE 2

Chemical composition of breadfruit meal" and maize, $\mathrm{g} \mathrm{kg}^{-1} \mathrm{DM}$ (except ME)

\begin{tabular}{|c|c|c|c|}
\hline Component & Breadfruit meal & Maize & BFM:Maize \\
\hline \multicolumn{4}{|l|}{ Proximate analysis } \\
\hline dry matter & 884.2 & 887.5 & 1.00 \\
\hline crude protein & 61.5 & 89.2 & 0.69 \\
\hline ether extract & 13.8 & 44.8 & 0.31 \\
\hline crude fibre & 111.4 & 19.3 & 5.77 \\
\hline ash & 70.0 & 19.0 & 3.68 \\
\hline nitrogen-free extractives & 627.5 & 715.2 & 0.88 \\
\hline \multicolumn{4}{|l|}{ Amino acid } \\
\hline alanine & 1.2 & 6.8 & 0.18 \\
\hline arginine & 4.9 & 4.0 & 1.23 \\
\hline aspartic acid & 3.2 & 10.8 & 0.30 \\
\hline cystine & 2.6 & 1.9 & 1.37 \\
\hline glutamic acid & 5.4 & 18.3 & 0.30 \\
\hline glycine & 1.1 & 2.7 & 0.41 \\
\hline histidine & 1.6 & 2.0 & 0.80 \\
\hline isoleucine & 3.6 & 3.4 & 1.06 \\
\hline leucine & 12.2 & 11.8 & 1.03 \\
\hline lysine & 5.8 & 2.4 & 2.42 \\
\hline methionine & 2.2 & 1.9 & 1.16 \\
\hline phenylalanine & 5.0 & 4.6 & 1.09 \\
\hline proline & 1.7 & 10.2 & 0.17 \\
\hline threonine & 3.6 & 2.9 & 1.24 \\
\hline tryptophan & 1.7 & 0.6 & 2.83 \\
\hline serine & 1.2 & 5.6 & 0.21 \\
\hline valine & 5.9 & 5.4 & 1.09 \\
\hline $\mathrm{ME}, \mathrm{MJ} \mathrm{kg}^{-1 \mathrm{~b}}$ & 12.89 & 14.02 & 0.92 \\
\hline
\end{tabular}

a values are the means of three samples

${ }^{b}$ estimated according to the method of Hill et al. (1960) 


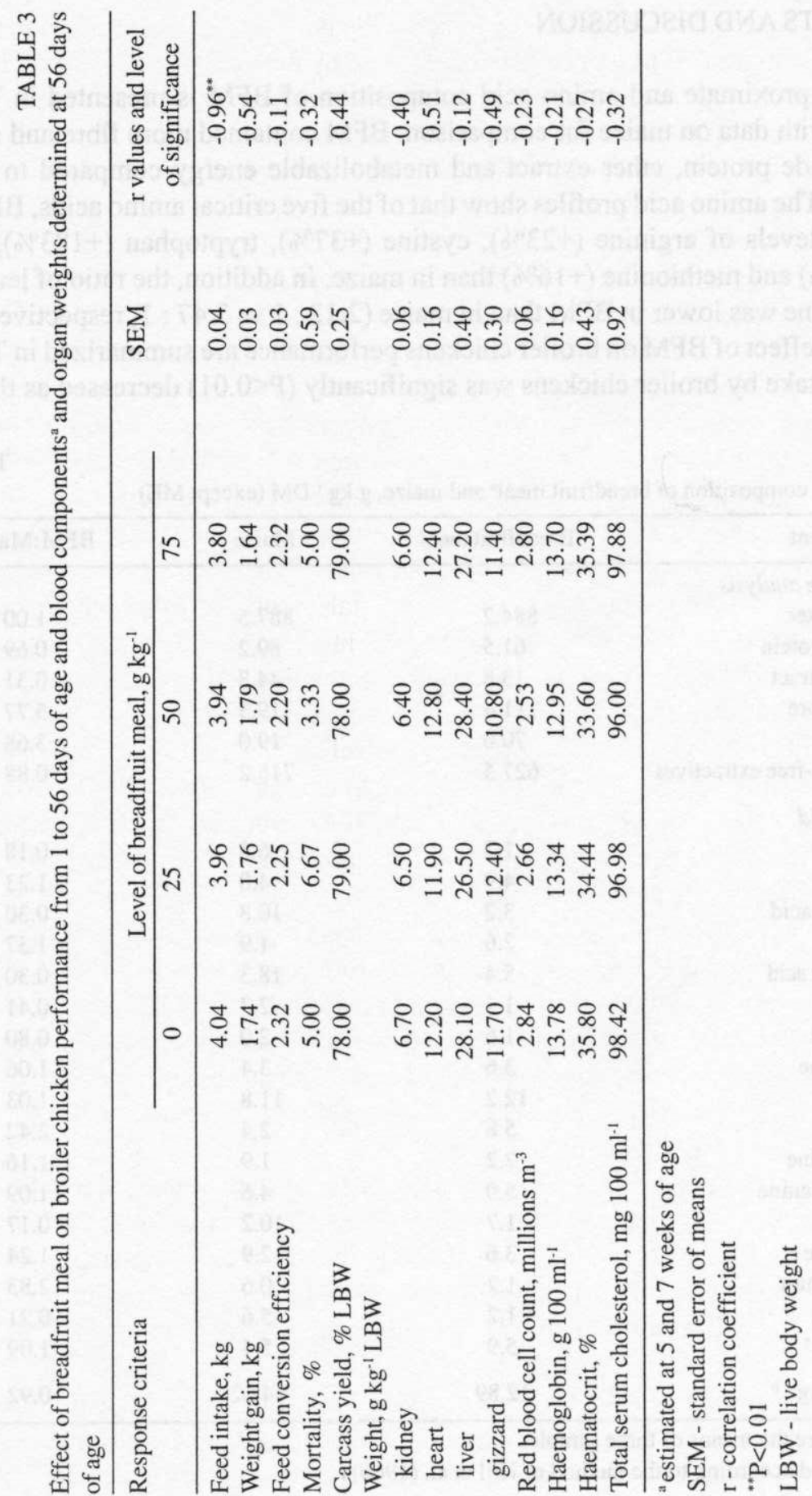


of BFM in the diets increased. The relationship between feed consumption ( $Y$ ) and the proportion of BFM $(X)$ could be described by the equation: $Y=4.05-0.003 X$ $(\mathrm{r}=-0.96 ; \mathrm{P}<0.01)$. A major factor affecting feed consumption in poultry is the dietary energy content because birds eat to satisfy their inner metabolic need for energy. In this experiment, however, feed consumption decreased with a decrease in dietary energy content. Many other factors including physical texture and protein content of the diet may also alter consumption by animals (Pond et al., 1995). It seems that in this case the reduced feed consumption was partly due to the dustiness or powdery nature of the diets incorporating BFM. On a per unit weight basis, breadfruit was dusticr or more powdery than maize milled under the same mesh size. This in effect increased the dustiness of the diets as the concentration of BFM in the diets increased. In general, texture may affect feed acceptability. Pelleting increases feed intake, while powdery feeds are eaten with difficulty. In addition, there was a tendency towards decreased dietary protein contents as the level of BFM in the diets increased. This might have also contributed to the decreased feed intake as the level of BFM in the diets increased. These results are in agreement with earlier studies (Smith, 1967; Osei and Effah-Baah, 1987) which indicated that high protein diets induced an increased feed intake by broilers and attributed the polyphagia to the fact that high protein diets induce appetite in chickens.

Breadfruit meal at 25 or $50 \mathrm{~g} \mathrm{~kg}^{-1}$ improved weight gains $(1-2 \%)$ and feed conversion efficiency (3-5\%) over the control diet. At the $75 \mathrm{~g} \mathrm{~kg}^{-1}$ diet level, however, BFM depressed weight gain $(5.7 \%)$ compared with the control but the efficiency of feed utilization was similar. All differences were statistically nonsignificant. The data in Table 1 indicated that as the level of BFM in the diets increased, the lysine contents of the diets slightly increased. There is little published literature on the use of BFM as a potential feed ingredient for poultry although work using raw BFM has been reported to produce less weight gain than cassava or maize, and also causes delayed maturity (Morton, 1987). The negative effects have been attributed to the cyclopropane-containing sterol, cycloartenol, which constitutes $12 \%$ of the non-saponifiable extract. Whether the depressive effect of the $75 \mathrm{~g} \mathrm{BFM} \mathrm{kg}^{-1}$ diet as observed in the present study was caused by cycloartenol is not clear since these were not studied.

Mortality among broilers fed the BFM-containing diets was similar to that on the BFM-free diet. Post-mortem autopsies indicated no specific causes for deaths attributable to BFM. There were no significant dietary effects on carcass yield, kidney, liver, heart and gizzard weights (Table 3). Similarly, no significant effects on the red blood cell count, haemoglobin, haematocrit and total serum cholesterol values were evident from feeding BFM.

It may be concluded that BFM, in combination with maize, can be used in broiler diets up to a level of $50 \mathrm{~g} \mathrm{~kg}^{-1}$ to cut down on the use of maize without sacrificing performance. It is, however, possible that if the toxic/antinutritional factor was re- 
moved it might be possible to include higher levels of BFM in broiler diets. A variety of detoxification methods including particularly boiling twice and discarding the water have been employed to make breadfruit safe for human consumption. Studies of processing technologies and treatments for improving the nutritive value of BFM for poultry are recommended. There are few named cultivars which reportedly, can be safely eaten without cooking and these need to be further investigated for their possible use in feeding poultry. Fats may also be used to increase the energy and palatability of the diets incorporating BFM, decrease the dustiness and improve the texture of the feed.

\section{ACKNOWLEDGEMENT}

The authors are grateful to Mohammed Rasheed Atiku and F.A. Kwarteng for technical assistance, T. Edusei for the chemical analysis and Ms. Gladys Ndziba for secretarial assistance.

\section{REFERENCES}

AOAC, 1990. Association of Official Analytical Chemists, Official Methods of Analysis. $15^{\text {th }}$ Edition. Arlington, VA

Christie G., 1978. Haematological and biological findings in anaemia induced by the daily bleeding of ten-week-old cockerels. Brit. Vet. J. 134, 358-365

Dacie J.V., Lewis S.M., 1975. Practical Haematology. $5^{\text {th }}$ Edition. Churchill Livingstone, Edinburgh

Hill F.W., Anderson D.L., Renner R.R., Carew L.B. Jr., 1960. Studies of the metabolisable energy of grain and grain products for chickens. Poultry Sci. 39, 573-597

Kirk RW., Bistner S.I., Ford R.B., 1990. Clinical procedures - blood collection. In: Handbook of Veterinary Procedures and Emergency Treatment. $5^{\text {th }}$ Edition. W.B. Saunders Company, Philadelphia, pp. 448-455

Maxwell M.H., 1981. Production of a Heinz body anaemia in the domestic fowl after ingestion of dimethyl disulphide: a haematological and ultrastructural study. Res. Vet. Sci. 30, 233-238

Miller E.L., 1967. Determination of the tryptophan content of feeding stuffs with particular reference to ccreals. J. Sci. Food Agr. 18, 381-386

Moore S., 1963. On the determination of cystine as cysteic acid. J. Biol. Chem. 238, 235-237

Morton J.F., 1987. Breadfruit. In: J.F. Morton (Editor). Fruits of Warm Climates. Miami, pp. 50-58

National Research Council, 1994. Nutrient Requirements of Domestic Animals. Nutrient Requirements of Poultry. $9^{\text {th }}$ revised Edition. National Academy Press, Washington, DC

Osei S.A., Effah-Baah K., 1987. Effects of varying protein levels on broiler performance when dietary energy levels remain constant. Ghana J. Agr. Sci. 20, 21-24

Pond W.G., Church D.C., Pond K.R., 1995. Factors affecting feed consumption. In: Basic Animal Nutrition and Feeding. $4^{\text {th }}$ Edition. John Wiley and Sons, New York, pp. 273-280

Smith R.E., 1967. The utilization of poultry diets containing high, low and intermediate levels of identical amino acid pattern. Poultry Sci. 46, 730-735 
Statistical Analysis Systems Institute Inc., 1987. Procedures Guide for Personal Computers, Version 6 Edition. SAS Institute lnc., Cary, NC

Stecl R.G.D., Torrie J.H., Dickey D.A., 1997. Principles and Procedures of Statistics. A Biometrical Approach. $3^{\text {rd }}$ Edition. McGraw-Hill, New York

Varley H., 1962. Practical Clinical Biochemistry. $3^{\text {rd }}$ Edition. Whitefriars Press, London

\section{STRESZCZENIE}

Zastosowanie mączki z owoców drzewa chlebowego (Artocarpus incicus) jako składnika mieszanek paszowych dla kurcząt brojlerów

W doświadczeniu pilotowym oznaczono wartość pokarmową mączki z owoców drzewa chlebowego (BFM) jako składnika mieszanek paszowych dla drobiu. Diety zawierające po $0,25,50$ lub $75 \mathrm{~g} \mathrm{BFM} / \mathrm{kg}$ podawano do woli 240 jednodniowym kurczętom przez 8 tygodni. Ptaki miały stały dostęp do wody. Oznaczano pobranie paszy, przyrosty, wykorzystanie paszy, upadki kurcząt oraz wydajność rzeźna, masę narządów wewnętrznych, a także niektóre wskaźniki krwi.

Pobranie paszy przez kurczęta zmniejszało się istotnie $(\mathrm{P}<0,01)$ wraz ze zwiększającym się udziałem BFM w mieszance (r=-0,96). Przy dawce 25 i $50 \mathrm{~g}$ BFM/kg paszy poprawiały się nieco przyrosty i wykorzystanie paszy, przy dawce 75 g BFM przyrosty były niższe, choć nicistotnic, a wykorzystanie paszy było podobne jak $w$ grupie kontrolnej. Nie stwierdzono wpływu udziału BFM w dawkach na wydajność rzeźną i ciężar nerek, serca, wątroby i żołądka miçśniowego oraz liczbe padłych kurcząt i wskaźniki krwi.

W podsumowaniu stwierdzono, że mączka z owoców drzewa chlebowego może stanowić składnik dict dla kurcząt broilerów w ilości do $50 \mathrm{~g} / \mathrm{kg}$, bez ujemnego wpływu na wyniki produkcyjne. 